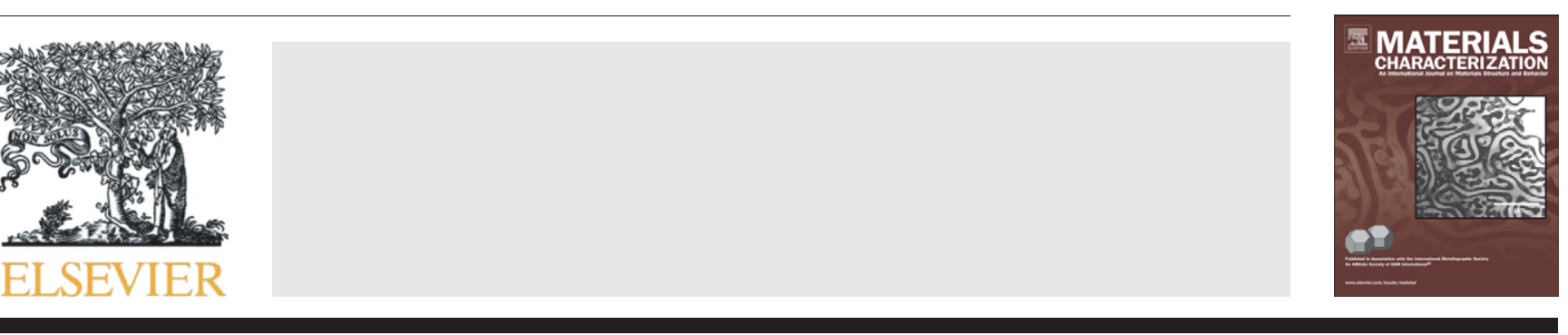

\title{
Properties of Roman bricks and mortars used in Serapis temple in the city of Pergamon
}

\author{
Özlem Aslan Özkaya, Hasan Böke* \\ Architectural Restoration Department, Izmir Institute of Technology, 35430 Izmir, Turkey
}

\section{A R T I C L E D A T A}

Article history:

Received 8 January 2009

Received in revised form 2 March 2009

Accepted 3 April 2009

Keywords:

Roman mortar

Roman brick

Pozzolana

Temple

Conservation

\begin{abstract}
A B S T R A C T
Serapis temple, which was constructed in the Roman period in the city of Pergamon (Bergama/Turkey), is one of the most important monuments of the world heritage. In this study, the characteristics of bricks and mortars used in the temple have been determined in order to define the necessary characteristics of the intervention materials, which will be used in the conservation works of the temple. Several analyses were carried out to determine their basic physical properties, raw material compositions, mineralogical and microstructural properties using X-ray diffraction, Scanning Electron Microscope and a Thermo Gravimetric Analyzer. Analysis results indicated that the mortars are stiff, compact and hydraulic due to the use of natural pozzolanic aggregates. The Roman bricks are of low density, high porosity and were produced from raw materials containing calcium poor clays fired at low temperatures.
\end{abstract}

() 2009 Elsevier Inc. All rights reserved.

\section{Introduction}

The most important thing to be considered in the conservation works of the ancient materials is that intervention materials should be compatible with the original material and should not do any damage in the long term. This requires knowing about the properties of original materials as well as the problems of deterioration. Use of wrong materials in the conservation works of ancient materials leads to rapid deterioration, causing lost of their historical, documental and esthetical values.

In this study, characteristics of ancient bricks and mortars used in the Serapis temple have been determined in order to define the characteristics of the intervention materials, which will be used in the conservation works of the temple.

The Serapis temple, built in Bergama/Turkey, was the largest Egyptian-style temple structure during the Hellenistic and Roman periods. It is one of the most important monuments of the world heritage (Fig. 1). The main structure of the temple, constructed of red bricks, is $60 \times 26 \mathrm{~m}$. In addition, there are two round structures, one either side, with a square atrium attached each to them and a large $100 \times 200 \mathrm{~m}$ atrium at the front of this structural complex. The height of the structure is $19 \mathrm{~m}$ at present [1].

\section{Experimental Methods}

In this study, three brick (RB 1-3) and two mortar (RM 1-2) samples were collected from the walls of the Serapis temple for the identification of their basic physical properties, microstructural features, mineralogical and chemical compositions.

Bulk density and porosity, the main physical properties of bricks and mortar samples, were determined by measuring the dry, water saturated under vacuum, and hydrostatic weights of samples [2]. Uniaxial compressive strength values (UCS) of brick and mortar samples were determined by using a Shimadzu AG-I Mechanical Test Instrument.

Lime and aggregate ratios of mortars were determined by dissolving the carbonated lime in mortars with dilute hydrochloric ( $\mathrm{HCl}$ ) acid [3]. Chemical compositions of lime lumps representing the lime used in Roman mortars were deter-

\footnotetext{
* Corresponding author. Tel.: +90 232 7507035; fax: +90 2327507012.

E-mail address: hasanboke@iyte.edu.tr (H. Böke).
} 


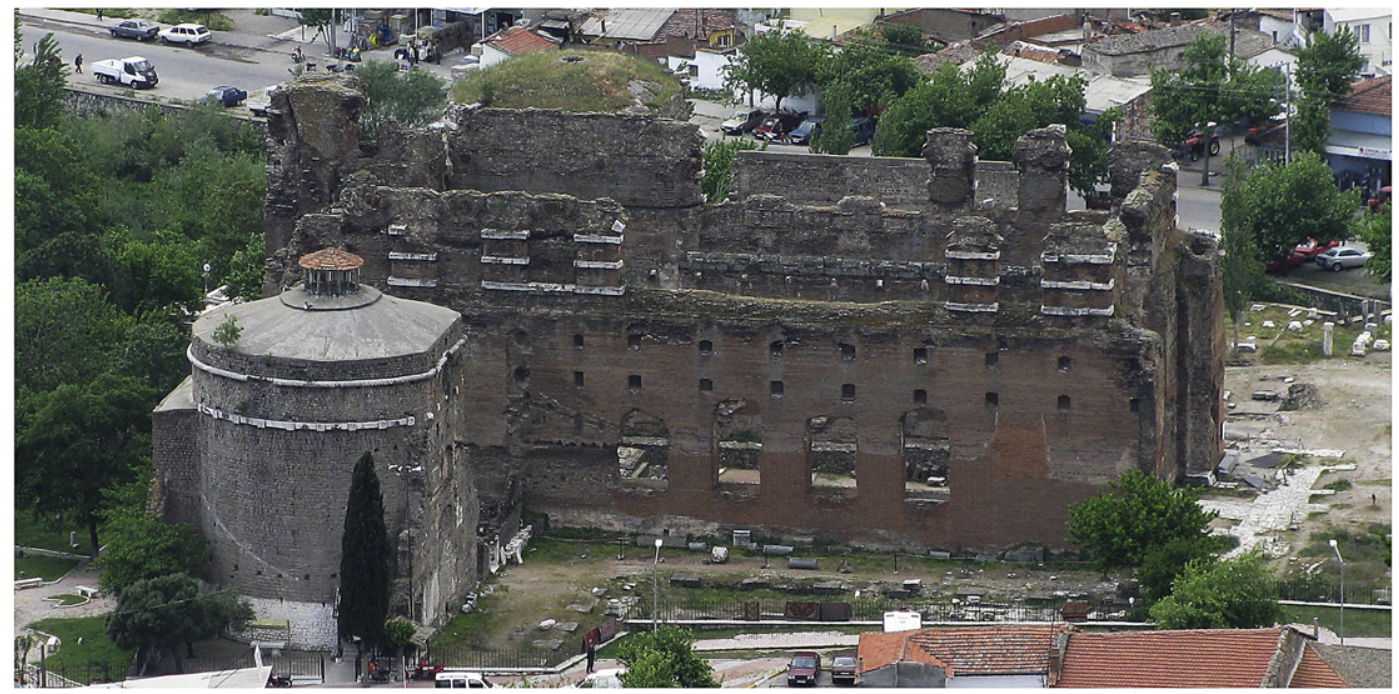

Fig. 1 - A view of the Serapis Temple from acropolis of Pergamon.

mined by SEM-EDS analyses. Pozzolanic activity of the powdered bricks and fine aggregates (less than $53 \mu \mathrm{m}$ size) were determined by measuring the differences in electrical conductivities $(\mathrm{mS} / \mathrm{cm})$ before and after addition of the samples into saturated calcium hydroxide solution [4].

Mineralogical compositions of bricks and mortars were identified by X-ray Diffraction (XRD) analyses performed by a Philips X-Pert Pro X-ray diffractometer. Their microstructures and chemical compositions were determined with a Philips XL 30S FEG Scanning Electron Microscope (SEM) coupled with X-Ray Energy Dispersive System (EDS). The hydraulic property of the mortar was evaluated at temperatures between 200 and $600{ }^{\circ} \mathrm{C}$ by determining its weight loss due to the loss of the structurally bound water of hydraulic products, such as calcium silicate hydrates and calcium aluminate hydrates. Weight loss due to carbon dioxide released during the decomposition of calcium carbonates at temperatures over $600^{\circ} \mathrm{C}$ was accomplished using a Shimadzu TGA-51 [5].

\section{Results and Discussion}

\subsection{Characteristics of Roman Bricks}

Brick is the most ancient manmade building material. It is produced through the process of mixing sifted raw materials containing quartz, feldspar and clay with water and then shaping, drying and baking. Bricks were first used in Mesopotamia for a long time for water tight constructions, such as water troughs or pipes, and for more vulnerable parts of the buildings, such as the frames of openings or the facings of large monuments [6]. Greeks and Romans used bricks much later as tiles and roof decorations for waterproof covering and as protection for the ends of the roof timbers.

In this study, analysis indicated that Roman bricks used in the Serapis temple have a low density $\left(1.65 \mathrm{~g} / \mathrm{cm}^{3}\right)$, a high porosity $(35 \%)$ and low compressive strength values ( 6.0 MPa).

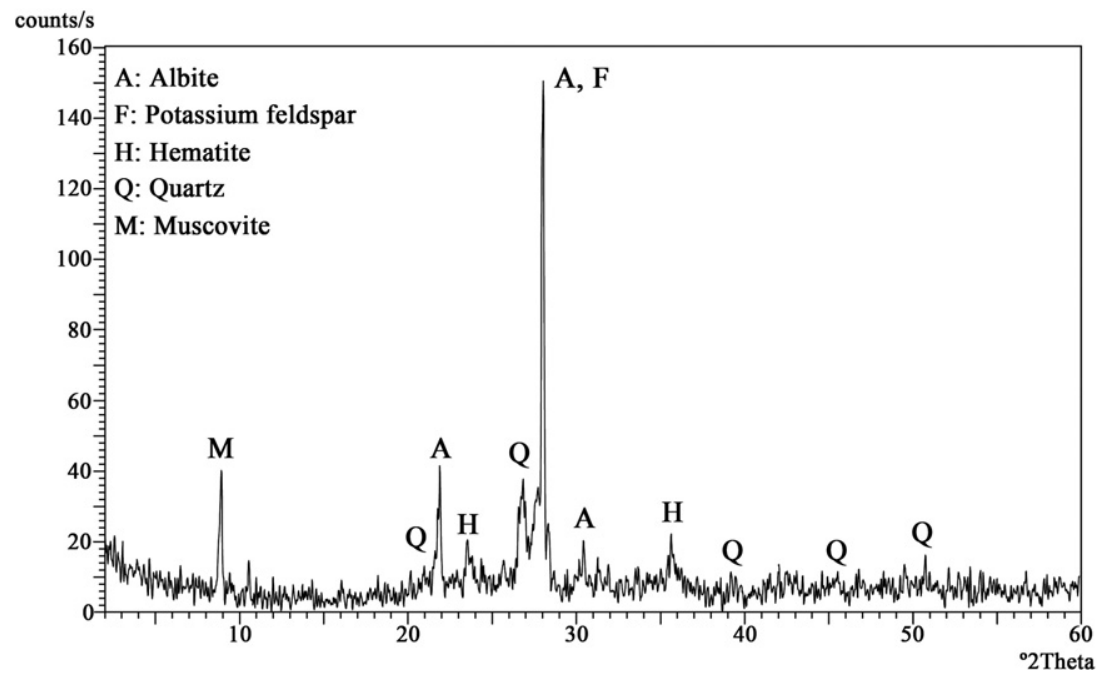

Fig. 2 - XRD pattern of the Roman brick sample (RB-1) with peaks of albite, potassium feldspar, hematite, quartz and muscovite minerals. 


\begin{tabular}{|c|c|c|c|c|c|c|c|}
\hline Samples & $\mathrm{Na}_{2} \mathrm{O}$ & $\mathrm{K}_{2} \mathrm{O}$ & $\mathrm{MgO}$ & $\mathrm{CaO}$ & $\mathrm{Fe}_{2} \mathrm{O}_{3}$ & $\mathrm{Al}_{2} \mathrm{O}_{3}$ & $\mathrm{SiO}_{2}$ \\
\hline RB-1 & $2.4 \pm 0.3$ & $3.3 \pm 0.5$ & $3.9 \pm 0.1$ & $3.8 \pm 0.4$ & $11.4 \pm 2.3$ & $17.6 \pm 0.3$ & $57.5 \pm 2.7$ \\
\hline RB-2 & $3.4 \pm 0.4$ & $3.6 \pm 0.5$ & $3.1 \pm 0.5$ & $4.4 \pm 0.7$ & $9.7 \pm 1.5$ & $17.8 \pm 0.1$ & $58.1 \pm 1.3$ \\
\hline RB-3 & $3.0 \pm 0.4$ & $4.6 \pm 0.4$ & $4.0 \pm 0.5$ & $4.2 \pm 0.4$ & $11.2 \pm 2.4$ & $17.0 \pm 0.4$ & $56.0 \pm 2.1$ \\
\hline
\end{tabular}

Similar physical properties found in Roman bricks used in historic structures in Toledo, Spain and Sicily show the use of the same production steps of bricks from the early Roman period $[7,8]$.

Mineralogical analysis conducted by XRD showed that Roman bricks were mainly composed of quartz, albite, potassium feldspar, hematite and muscovite minerals (Fig. 2). Calcium compounds were not observed in the XRD spectrum of the sample. These results show that bricks were produced by earthen materials containing calcium poor clays and low amounts of calcite minerals [8].

The firing temperature ranges of the bricks were estimated by X-ray analysis. The presence of hematite minerals showed that the firing temperature of the bricks was nearly $850{ }^{\circ} \mathrm{C}[8]$. In addition, the absence of high temperature products of clay minerals such as mullite and crystoballite minerals in the XRD patterns indicates the firing temperature of the bricks did not exceed $900^{\circ} \mathrm{C}[9]$.

The elemental compositions and the microstructural characteristics of the bricks were determined by SEM-EDS analysis (Table 1). Analysis results show that the bricks contain high amounts of $\mathrm{SiO}_{2}, \mathrm{Al}_{2} \mathrm{O}_{3}$, and $\mathrm{Fe}_{2} \mathrm{O}_{3}$, and low amounts of $\mathrm{Na}_{2} \mathrm{O}$, $\mathrm{K}_{2} \mathrm{O}, \mathrm{MgO}$, and $\mathrm{CaO}$. The presence of low amounts of Ca in their composition supports the notion of the use of calcium poor clays from locally available raw materials sources.

Microstructural characteristics of the bricks showed that they contained small pieces of broken brick (grog) fragments (Fig. 3) and trace amounts of metal compounds such as titanium oxide, copper oxide and zirconium silicate (Fig. 4). The presence of grog particles in the raw materials of bricks may be explained as a means of reducing the addition of large amounts of water that aids in the extrusion but delays the drying stages of brick production [10].

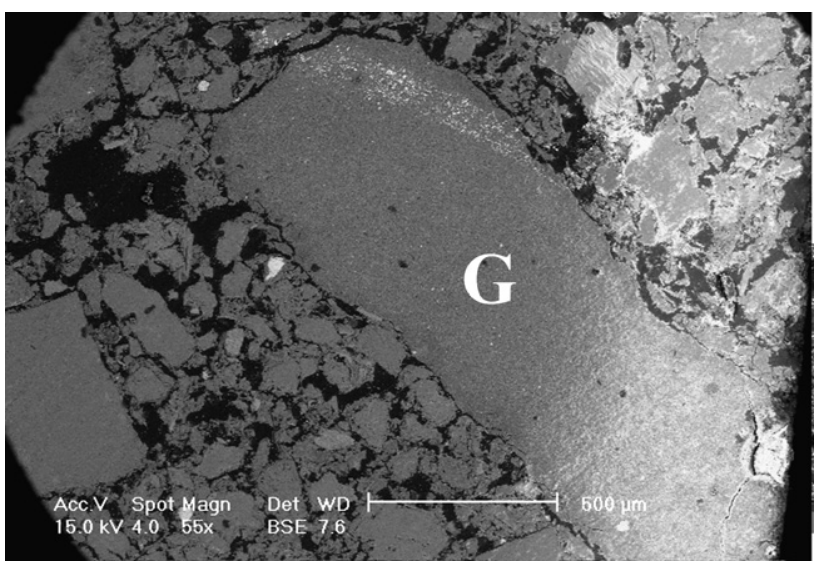

Fig. 3 - BSE image of a waste fired brick particle (Grog:G) in the brick matrix.
The pozzolanic activity value of brick powders shows that electrical conductivity difference values are less than $1.2 \mathrm{mS} / \mathrm{cm}$ [4]. This may indicate that the raw materials containing clay minerals were not enough to produce high amounts of pozzolanic amorphous substances. Similar results were also observed in the bricks used in some other historic structures [11].

\subsection{Characteristics of Roman Mortars}

Lime mortars, produced by mixing lime and aggregates, have been the most basic and common binding material used in the construction of buildings from the ancient Greek, Roman and the succeeding periods up to the discovery of cement [12]. It was known that the Romans used well-slaked lime and the clean flat sides of aggregates [13]. Some of the Roman mortars were prepared by mixing lime and aggregates in a large bowl with a little amount of water [13]. The lime and aggregates

(a)

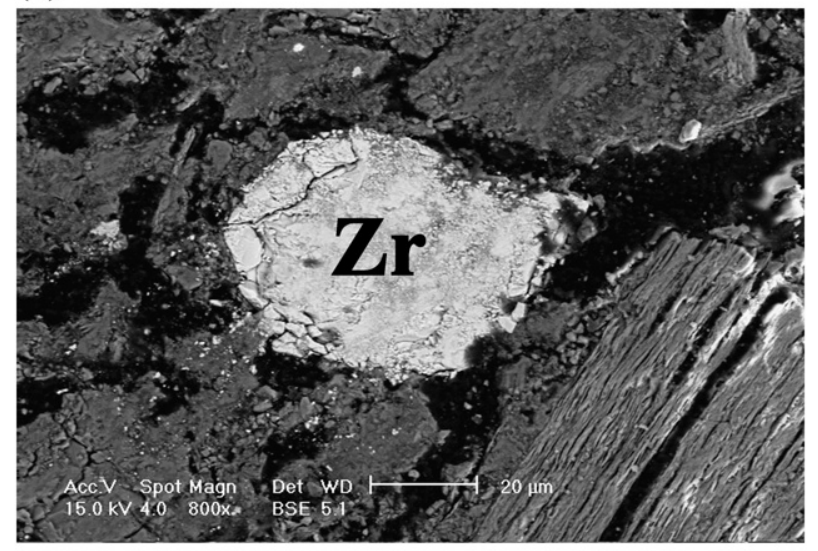

(b)

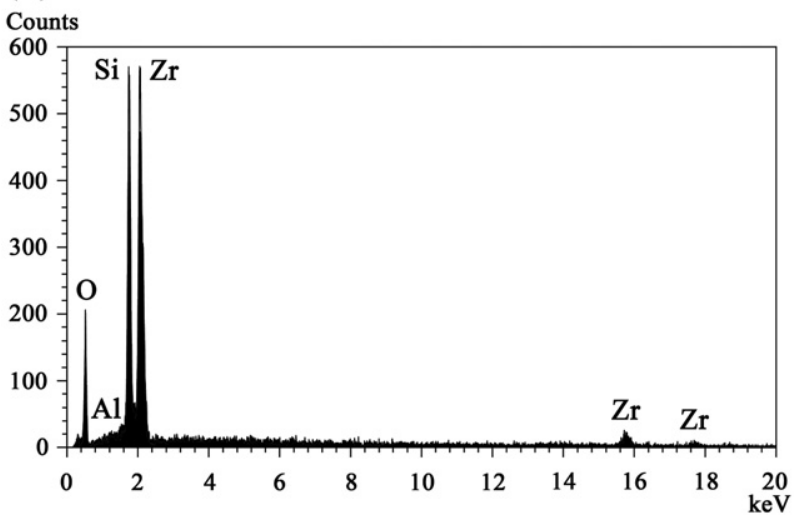

Fig. 4 - BSE image (a) and EDX spectrum (b) of a tiny zircon (zirconium silicate: Z) particle in the brick matrix (RB-1). 


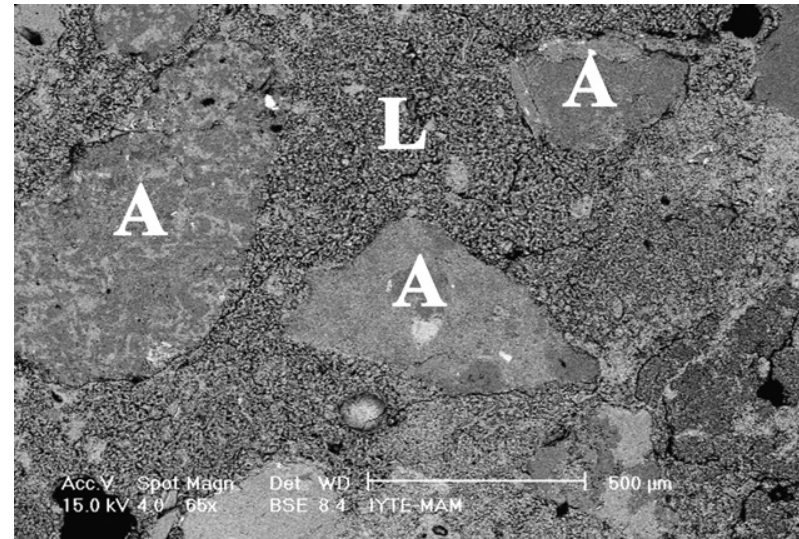

Fig. 5 - BSE image showing good adhesion between aggregates and lime (A: Aggregate, L: Lime).

stick to each other better and the voids between the aggregates are filled with lime. This mixture was used after setting for at least 3 years.

The mortars used in many Roman Period structures such as the Pantheon and Collesium, Sagalassos, Tournai Cathedral, and the Domitilla catacombs are known hydraulics that were prepared using natural pozzolans [14-17]. Baked ceramic materials, such as bricks and tiles were also used as an artificial pozzolan in the mortars and plasters of many Roman structures. Those mortars and plasters were known as Cocciopesto in the Roman Period [14]. They were used for walls as a surface rendering exposed to severely humid environments such as thermal baths or foundations where the water table was high [18].

In the present study, the characteristics of the mortars used in the Serapis temple have been determined in order to produce a similar mortar for intervention. These mortars were mainly composed of lime and natural aggregates. The lime/ aggregate ratios were around 1:4 by weight and the aggregates with particle sizes greater than $1180 \mu \mathrm{m}$ composed the largest fraction of the total aggregates.

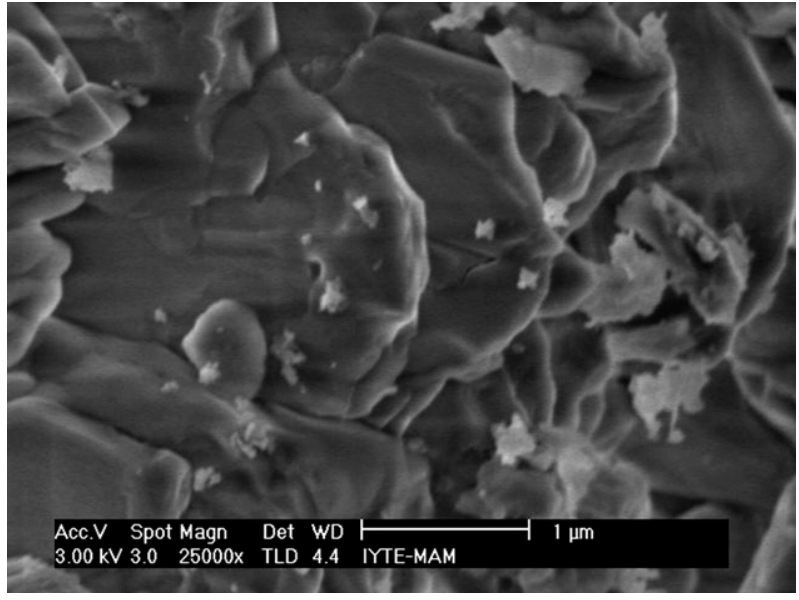

Fig. 7 - SE image of glassy phases in the volcanic aggregate of Roman mortar (RM-1).

The mortars are stiff, hard and compact due to strong cohesion between aggregates and lime (Fig. 5). The aggregates are mostly semi-rounded, mainly soft, easily granulated and very porous permitting strong adherence to the lime. The density and porosity values of mortars were $1.5 \mathrm{~g} / \mathrm{cm}^{3}$ and $36 \%$, by volume, respectively. Their compressive strength and modulus of elasticity values were $6.6 \mathrm{MPa}$ and $630.6 \mathrm{MPa}$, respectively. These results show that mortars used in the temple were physically compatible with Roman bricks.

Chemical compositions of lime determined by SEM-EDS analyses indicated that it was mostly composed of $\mathrm{CaO}$. High $\mathrm{CaO}$ content shows that the lime was obtained from pure calcareous stones. Similar results have also been found from the mortars used in some Roman structures in Italy [19].

Pozzolanicity of fine agregates of mortars was investigated by XRD, SEM-EDS analysis and measuring the differences in electrical conductivities before and after addition of aggregates into saturated calcium hydroxide solution by electrical conductivity measurements.

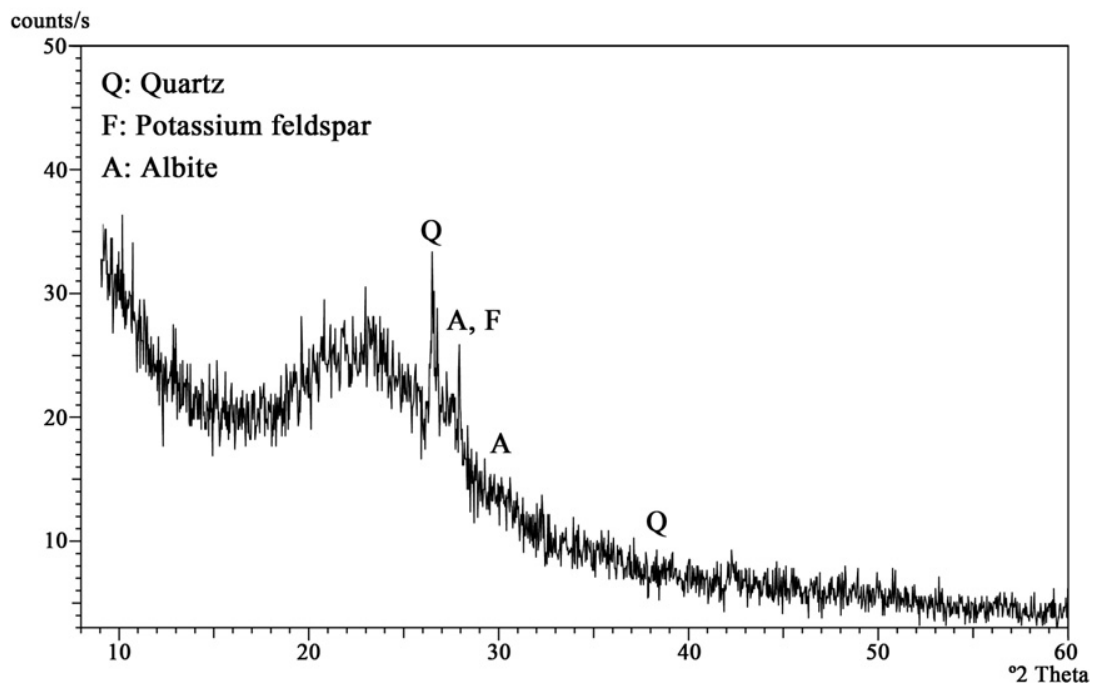

Fig. 6 - XRD pattern of the fine aggregates used in Roman mortar with a broad peak of amorphous silica between 20 and $30^{\circ}$. 
XRD patterns of fine aggregates showed that they were composed of albite, $\mathrm{K}$-feldspar, quartz and amorphous minerals indicated by the broad peak between 20 and $30^{\circ}$ in the diffraction pattern (Fig. 6). SEM analysis indicated that they were mainly composed of glassy phases of silica (Fig. 7). In electrical conductivity measurements, the high differences in electrical conductivities values $(7 \mathrm{mS} / \mathrm{cm})$ of saturated calcium hydroxide solution before and after the addition of aggregates were observed. All these results indicate that the fine aggregates were volcanic with pozzolanic amorphous silica which produces a hydraulic character in the mortar.

The mortar matrices, composed of fine aggregates and lime, exhibited a uniform structure indicative of thorough mixing. Within the matrices, gel like formations composed mainly of calcium, silicon and aluminum were observed (Fig. 8). This may indicate the formation of hydraulic products (calcium silicate hydrates and calcium aluminate hydrates) formed by the reaction with lime and pozzolanic fine aggregates [20]. Formation of these compounds provides strong adhesion bonds which make the mortar durable and stiff.

The hydraulicity of the Roman mortars was evaluated by thermo gravimetric analyses (TGA). These analyses indicated that the Roman mortar samples contained $2.33 \%$ structurally bound water between $200{ }^{\circ} \mathrm{C}$ and $600{ }^{\circ} \mathrm{C}$ and $6.87 \%$ carbon dioxide over $600{ }^{\circ} \mathrm{C}$ (Fig. 9). The $\mathrm{CO}_{2} / \mathrm{H}_{2} \mathrm{O}$ ratio was 2.95. This

(a)

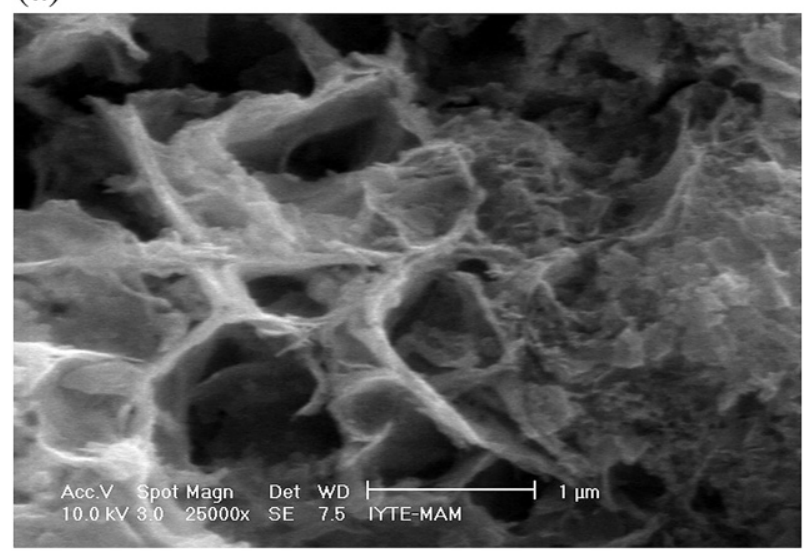

(b)

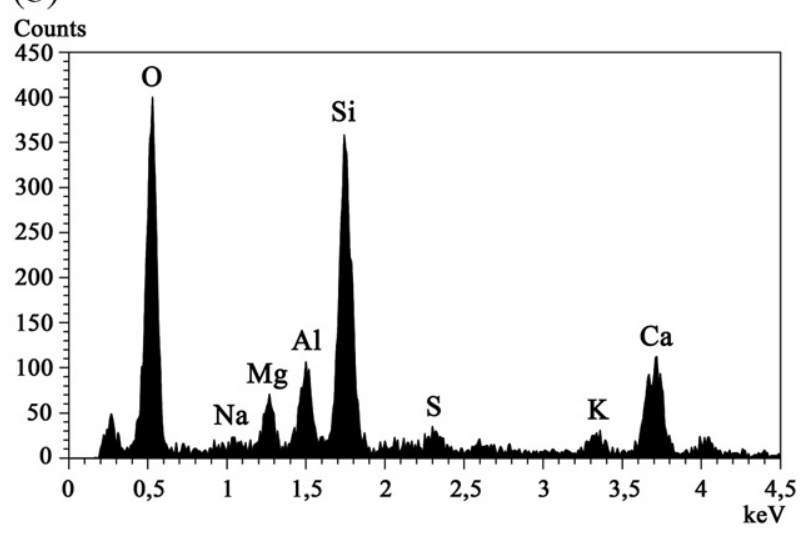

Fig. 8 - SE images of calcium aluminum silicate hydrate formation in Roman mortar (a) and its EDS spectrum (b).

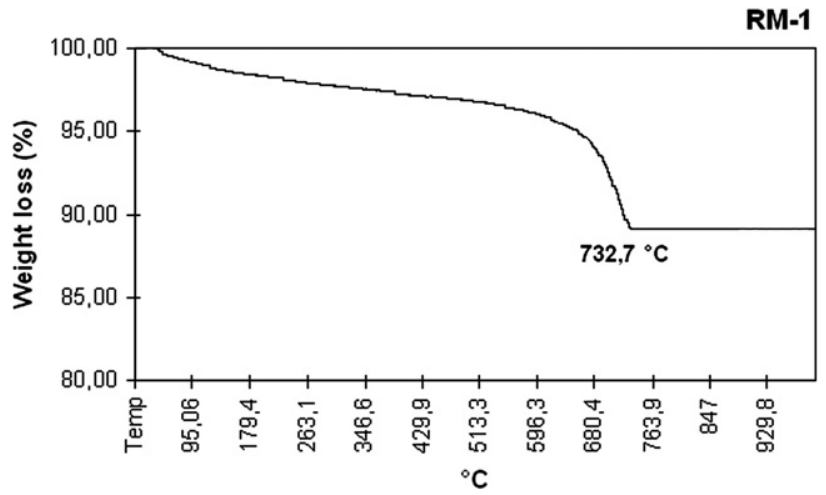

Fig. 9 - TGA graph of the Roman mortar matrix with fine aggregates (RM-1).

result shows that Roman mortars can be regarded as hydraulic lime mortars [5].

\section{Conclusion}

Roman bricks and mortars used in the construction of Serapis temple have nearly the same physical and mechanical properties throughout the structure. They are of low density, high porosity and have high compressive strengths and modulus of elasticity values.

The bricks were manufactured from locally available raw material sources containing calcium poor clays. They have poor pozzolanicity due to lesser amounts of amorphous materials. They were lightly vitrified and fired at low temperatures, 600 to $900{ }^{\circ} \mathrm{C}$.

Roman mortars are composed of pure lime, coarse aggregates with particle sizes greater than nearly $1 \mathrm{~mm}$ and pozzolanic fine aggregates. Due to the use of pozzolanic aggregates, Roman mortars are hydraulic.

New mortars and bricks used for the conservation work of temple should have similar compositions to those of the original mortars and bricks in order to keep the structure sound and durable.

\section{Acknowledgments}

The authors thank the researchers of the Centre for Materials Research at the Izmir Institute of Technology for XRD and SEM-EDS analyses during the experimental stage of this study.

\section{R E F E R E N C E S}

[1] Radt W. Pergamon. Antik Bir Kentin Tarihi ve Yapıları. İstanbul: Yapı Kredi Yayınları; 2002.

[2] RILEM. Tests defining the structure. Mater Cons 1980;13:73.

[3] Jedrzejevska H. Ancient mortars as criterion in analysis of old architecture. Proc of symp on mortars, cements and grouts used in the conservation of historic buildings. Rome; 1981. November 3-6. 
[4] Luxán MP, Madruga F, Saavedra J. Rapid evaluation of pozzolanic activity of natural products of conductivity measurement. Cem Concr Res 1989;19:63-8.

[5] Moropoulou A, Bakolas A, Bisbikou K. Investigation of the technology of historic mortars. J Cult Heritage 2000;1:45-58.

[6] Adam JP. Roman buildings: materials and techniques. London: Taylor \& Francis; 1999.

[7] Lopez-Arce P, Garcia-Guinea J. Weathering traces in ancient bricks from historic buildings. Build Environ 2005;40 (7):929-41.

[8] Cardiano P, Ioppolo S, Stefano CD, Pettignano A, Sergi S, Piraino P. Study and characterization of the ancient bricks of monastery of 'San Filippo di Fragalá' in Frazzanò (Sicily). Anal Chim Acta 2004;519:103-11.

[9] Sujeong L, Kim YJ, Moon HS. Phase transformation sequence from kaolinite to mullite investigated by an energy-filtering transmission electron. J Am Ceram Soc 1999;10:2841-8.

[10] Vieira CMF, Monteiro SN. Effect of grog addition on the properties and microstructure of a red ceramic body for brick production. Constr Build Mater 2007;21:1754-9.

[11] Baronio G, Binda L. Study of the pozzolanicity of some bricks and clays. Constr Build Mater 1997;11(1):41-6.

[12] Cowper A. Lime and lime mortars. London: Donhead; 1988.

[13] Peter N. Encylopedia of architecture. New York: Fry \& Co; 1850.
[14] Massazza F, Pezzuoli M. Some teachings of a Roman concrete mortars. Proc of symp on mortars, cements and grouts used in the conservation of historic buildings. Rome; 1981. November 3-6.

[15] Degryse P, Elsen J, Waelkens M. Study of ancient mortars from Sagalassos (Turkey) in view of their conservation. Cem Concr Res 2002;32:1457-63.

[16] Elsen J, Brutsaert A, Deckers M, Brulet R. Microscopical study of ancient mortars from Tournai (Belgium). Mat Charac 2004;53:289-94.

[17] Sánchez-Moral S, Luque L, Cañaveras JC, Soler V, Garcia-Guinea J, Aparicio A. Lime pozzolana mortars in Roman catacombs: composition, structures and restoration. Cem Concr Res 2005;35(8):1555-65.

[18] Böke H, Akkurt S, İpekoğlu B, Uğurlu E. Characteristics of brick used as aggregate in historic brick-lime mortars and plasters. Cem Concr Res 2006;36(6):1115-22.

[19] Pavia S, Caro S. An investigation of Roman mortar technology through the petrographic analysis of archaeological material. Constr Build Mater 2008;22:1807-11.

[20] Haga K, Shibata M, Hironaga M, Tanaka S, Nagasaki S. Silicate anion structural change in calcium silicate hydrate gel on dissolution of hydrated cement. J Nucl Sci Tech 2002;39 (5): 540-7. 